\title{
Peranan Badan Permusyawaratan Desa Dalam Perencanaan Pembangunan di Desa Dulohupa Kecamatan Boliyohuto
}

\author{
${ }^{1}$ Harijono Imbran, ${ }^{2}$ Yusrin Hakim \\ ${ }^{1}$ Program Studi Ekonomi Pembangunan Universitas Muhammadiyah Gorontalo \\ ${ }^{2}$ Program Studi Administrasi Negara Universitas Muhammadiyah Gorontalo \\ Gorontalo,Indonesia \\ Email:11041965hari@gmail.com,yusrin.hakim@yahoo.com
}

\begin{abstract}
Development in an effort to humanize human beings by nature is also a business that has the meaning of ethics, law, and the values of religious teachings in both the objectives to be achieved in the way of business execution and achieve national development objectives. development in the Village Dulohupa that until now there are still many obstacles in the implementation of its development. The purpose of this study was to obtain information the extent of the role of the Village Consultative Body in supporting rural development in the Village Dulohupa Boliyohuto District of Gorontalo district. This study uses qualitative research with descriptive methods. Data collection techniques articles used were interviews, observation, and documentation. In this study informants ad 9 block, in an interview. The results showed that the role of the Village Consultative Bdan very important for the growth masyarakatn welfare and rural development. In accommodating issues and development in the village, $B P D$ also plays quite well, although sometimes seen lonely office in the village BPD Dulohupa resulting difficulties in gathering to share their aspirations and ideas as well as ideas.
\end{abstract}

Keywords: Role, Agency Village Permusyawaratn and Rural Development

\begin{abstract}
Abstrak
Pembangunan sebagai usaha memanusiakan manusia pada hakikatnya juga merupakan usaha yang mempunyai makna etik, hokum, serta nilai ajaran agama baik dalam tujuan yang ingin dicapai maupun dalam cara pelaksanaan usaha mencapai tujuan pembangunan nasional. pembangunan di Desa Dulohupa yang sampai saat ini masih terdapat banyak hambatan dalam pelaksanaan pembangunannya. Tujuan dari penelitian ini adalah untuk memperoleh informasi sejauh mana Peran Badan Permusyawaratan Desa dalam menunjang pembangunan desa di Desa Dulohupa Kecamatan Boliyohuto Kabupaten Gorontalo. Penelitian ini menggunakan penelitian kualitatif dengan metode deskriptif. Tehnik pengumpulan data yang digunakn adalah wawancara, observasi, dan dokumentasi. Dalam penelitian ini ad 9 orang informan yand di wawancara. Hasil penelitian menunjukan bahwa Peran Bdan Permusyawaratan Desa sangat penting bagi pertumbuhan kesejahteraan masyarakatn dan pembangunan desa. Dalam mengakomodasi permasalahan dan pembangunan di desa, BPD juga sudah berperan cukup baik, meskipun kadang kala terlihat sepinya kantor BPD di Desa Dulohupa yang mengakibatkan susahnya masyarakat untuk menyalurkan aspirasi, ide serta gagasan.
\end{abstract}

Kata Kunci : Peran, Badan Permusyawaratan Desa, dan Pembangunan Desa 


\section{PENDAHULUAN}

Dalam rangka pelaksanaan otonomi daerah akan sangat bergantung pada kesiapan Pemerintah Daerah dalam menata sistem pemerintahannya agar tercipta pembangunan yang efektif, efesien, transparansi, dan akuntabel serta mendapat partisipasi dari masyarakat dalam penyelenggaraan pemerintahannya. Sesuai dengan amanat Undang-undang No.32 Tahun 2004 tentang Pemerintahan Daerah, bahwa dalam penyelenggaraan otonomi daerah dipandang perlu untuk menekankan pada prinsip-prinsip pemerintahan yang baik (Good Governance) dan pemerintahan yang bersih ( Clean Governance ) dalam mewujudkan pembangunan daerah yang desentralistik dan demokratis.

Maka dalam penyelenggaraan pembangunan desa diperlukan pengorganisasian yang mampu menggerakkan masyarakat untuk mampu berpatisipasi dalam melaksanakan pembangunan desa serta melaksanakan administrasi pembangunan desa. Dengan demikian diharapkan pembangunan dan pelaksanaan administrasi desa akan berjalan lebih rasional, tidak hanya didasarkan pada tuntutan emosional yang sukar dipertanggungjawabkan kebenarann ya.

Berdasarkan uraian tersebut, maka dapat diidentifikasi masalah sebagai berikut :
1. Kurangnya peran serta Badan Permusyawaratan Desa Dulohupa dalam pembangunan desa.

2. Kurangnya kerja sama antar anggota Badan Permusyawaratan Desa Dulohupa dalam perencanaan pembangunan desa.

Adapun tujuan yang penulis harapkan dapat dicapai melalui penelitian ini adalah untuk mengetahui sejauh mana peranan Badan Permusyawaratan Desa (BPD) dalam perencanaan pembangunan desa di Desa Dulohupa Kecamatan Boliyohuto.

\section{METODE PENELITIAN}

Metode penelitian yang dipergunakan adalah metode deskriptif kualitatif yaitu yang dapat diartikan menurut Nawawi (1983:63) sebagai pemecahan masalah yang diselidiki dengan menggambarkan keadaan subjek atau objek penelitian seseorang, lembaga, masyarakat, dan lain-lain pada saat sekarang berdasarkan fakta-fakta yang nampak atau sebagaimana adanya.

Sumber data merupakan faktor dominan dalam penelitian. Untuk hal ini, penulis memilah sumber data sebagai berikut :

a. Data Primer atau sumber data berupa orang yakni, orang-orang yang berhubungan baik langsung maupun tak langsung. Dalam penelitian ini orang yang menjadi sumber data ialah Ketua BPD Desa Dulohupa dan anggotanya, Kepala Desa Dulohupa dan Staf Desa, serta masyarakat. Untuk itu pula penulis melampirkan data informan.

b. Data Sekunder atau data berupa dokumen. Dalam hal ini, sumber data baik berupa foto, dan lain-lain. Dalam hal ini, maka penulis mencantumkan pula sumber-sumber data penelitian tersebut baik dalam daftar data tabel maupun berupa daftar pustaka.

Data yang dikumpulkan dalam penelitian ini terdiri dari data primer dan data sekunder, dengan perincian sebagai berikut:

1. Data primer diperoleh melalui :

a. Wawancara, yaitu melakukan tanyajawab langsung dengan pihak 
yang terkait mengenai hal-hal yang belum jelas, untuk pelengkap perolehan data informasi. Wawancara alat utama dalam penelitian deskriptif kualitatif.

b. Observasi, yaitu melakukan pengamatan langsung dengan melakukan pencatatan terhadap gejalagejala yang dijumpai di lapangan.

2. Data sekunder diperoleh melalui :

a. Penelitian Kepustakaan, dilakukan dengan mempelajari sejumlah tulisan, buku, karangan ilmiah serta peraturan perundangan yang relevan dengan penelitian ini.

b. Penelitian lapangan, dimana data diperoleh dengan melakukan studi lapangan.

\section{HASIL PEMBAHASAN}

Secara administrasi Desa Dulohupa terletak di wilayah Kecamatan Boliyohuto Kabupaten Gorontalo.Desa Dulohupa secara administratif terbagi menjadi 2 (dua) dusun yaitu Dusun Pone dan Dusun Gelora. Adapun batas-batas wilayah desa Dulohupa adalah sebagai berikut:

- Sebelah Utara berbatasan dengan Desa Iloheluma

- Sebelah Timur berbatasan dengan Desa Parungi

- Sebelah Barat berbatasan dengan Desa Motoduto

- Sebelah Selatan berbatasan dengan Desa Suka Damai

Penduduk merupakan unsur terpenting bagi desa yang meliputi jumlah, pertambahan, kepadatan, persebaran dan mata pencaharian penduduk desa setempat (Bintarto, 1983:13). Jumlah penduduk di Desa Dulohupa tahun 2015 beijumlah 537 jiwa dengan rincian penduduk laki-laki beijumlah 273 jiwa dan penduduk perempuan beijumlah 264 jiwa. Adapun jumlah penduduk dari 2 dusun yang ada di desa Dulohupa dapat dilihat dalam tabel sebagai berikut:
Tabel 1

Proporsi Penduduk Desa Dulohupa Menurut Jenis Kelamin

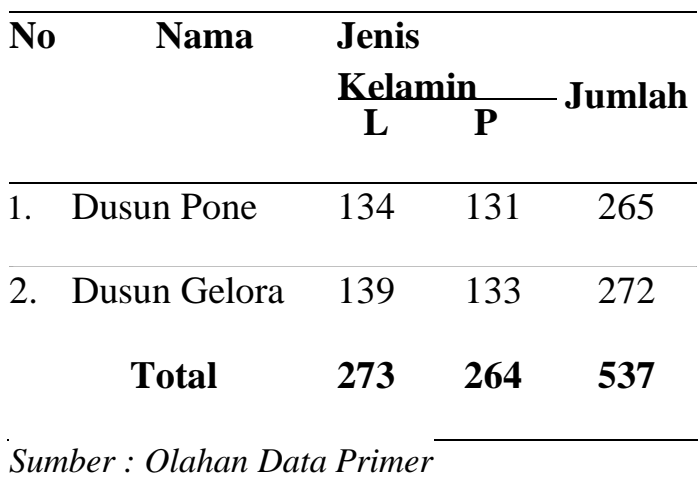

Berdasarkan data pada tabel 1, proporsi penduduk perempuan tidak berbeda secara signifikan yaitu 264 orang dibanding penduduk laki-laki 273 orang dari total penduduk di Desa Dulohupa. Dengan demikian dapat diketahui bahwa jenis kelamin perempuan penduduk Desa Dulohupa Kecamatan Boliyohuto didominasi oleh kaum laki-laki.

Tabel 2

Sarana dan Prasarana

\begin{tabular}{lllrl}
\hline No & Jenis & Jml & Jml & Kondisi \\
\hline 1. & Mck & 4 & 25 & Baik \\
2. & Sumur & 6 & 37 & Baik \\
3. & Sumur & 6 & 20 & Baik \\
4. & Perpipaan & 4 & 92 & Baik \\
5. & Jamban & 20 & 149 & Baik \\
& Total & $\mathbf{4 0}$ & $\mathbf{3 2 3}$ & \\
\hline
\end{tabular}

Sumber : Olahan Data Primer

Berdasarkan tabel di atas, dapat diketahui bahwa sarana pendukung untuk air minum di Desa Dulohupa sudah memadai. Hal ini terlihat dari kondisi sarananya yang rata-rata sudah baik.

Selanjutya pada tabel 3, dapat diketahui bahwa di Desa Dulohupa Kecamtan Boliyohuto Kabupaten Gorontalo hanya terdapat 2 sarana pendidikan yaitu TK/PAUD 1 Buah dan SLTP 1 buah. 
Tabel 3

Sarana Pendidikan

\begin{tabular}{clcc}
\hline No & Nama & Jumlah & Keterangan \\
1 & TK/ PAUD & 1 Buah & \\
2 & SD & - & \\
3 & SLTP & 1 Buah & \\
4 & SLTA & - & \\
\hline
\end{tabular}

Sumber : Olahan Data Primer

Anggota Badan Permusyawaratan Desa di Desa Dulohupa awalnya terdiri dari 7 orang. Namun dengan alasan tertentu maka 3 diantaranya telah mengundurkan diri. Setelah itu dalam menghadapi pilkades 2011 salah satu anggota mengundurkan diri lagi dengan alasan masuk dalam pencalonan pilkades tersebut. Akhimya Anggota Badan Permusyawaratan Desa Dulohupa sekarang sebanyak 3 orang. Kepengurusan terdiri dari satu orang Ketua, satu orang Sekretaris, dan satu orang Anggota yang dipilih secara demokratis diantara para anggota. Mereka dipilih oleh rakyat melalui pemilihan yang demokratis dengan mempertimbangkan keterwakilan dusun dalam pemilihan.

Biasanya masing-masing anggota Badan Permusyawaratan Desa diberikan tanggung jawab satu dusun tersebut dalam menyerapkan aspirasi penduduk desa, Karena jumlah anggota Badan Permusyawaratan Desa hanya 3 orang, sedangkan jumlah dusun yang ada di Desa Dulohupa sebanyak 2 dusun, maka duaorang dari anggota BPD memiliki tanggung jawab terhadap satu dusun. Agar proses penyerapan aspirasi penduduk lebih akurat, maka anggota BPD diberi tanggung jawab di dusun dimana dia bertempat tinggal.

Dalam menyerap aspirasi masyarakat ini, anggota BPD akan melakukan beberapa cara. Cara yang umum dilakukan oleh keseluruhan anggota BPD adalah dengan mengumpulkan masyarakat disalah satu rumah penduduk dusun ataupun rumah dari anggota BPD yang berada di dusun tersebut. Setelah penduduk dusun mengeluarkan aspirasinya masing-masing, tentunya aspirasi penduduk tersebut tidaklah sama antara individu yang satu dengan individu yang lain. Disitulah ditentukan rencana pembangunan yang mewakili aspirasi penduduk dusun dengan menetapkan prioritas-prioritas yang paling perlu.

Pelaksanaan mengenai tugas dan peran Anggota Badan Permusyawaratan Desa dalam pemerintahan merupakan salah satu bentuk kegiatan pemerintah dalam upaya meningkatkan kesejahteraan masyarakat,Untuk itu dalam melaksanakan tugasnya Anggota Badan Permusyawaratn Desa mempunyai peran:

- Kegiatan dalam rumah tangganya sendiri

- Menggerakkan partisipasi masyarakat

- Melaksanakan tugas dari pemerintah di atasnya

- Keamanan dan ketertiban masyarakat

- Melaksanakan tugas-tugas lain yang diberikan oleh pemerintah di atasnya Untuk menyelenggarakan peran tersebut diatas maka Anggota Badan

Permusyawaratan Desa harus mengusahakan :

- Terpenuhinya kebutuhan esensial masyarakat

- Tersusunnya rencana dan pelaksanaan pembangunan sesuai dengan kemampuan setempat

- Terselenggaranya program yang berkelanjutan

Berkaitan dengan pembangunan Desa Dulohupa di berbagai bidang tidak terlepas dari berbagai masalah yang mendapat perhatian dan segera 
diantisipasi, diantaranya:

a. Terbatasnya ketersediaan sumberdaya manusia yang baik dan profesional.

b. Terbatasnya ketersediaan sumbersumber pembiayaan yang memadai, baik yang berasal dari kemampuan desa itu sendiri (internal) maupun sumber dana dari luar (eksternal).

c. Belum tersusunnya kelembagaan sosial-ekonomi yang mampu berperan secara aktif.

d. Belum terbangunnya sistem dan regulasi yang jelas dan tegas.

e. Kurangnya kreativitas dan partisipasi masyarakat secara lebih kritis dan rasional.

Beberapa masalah pokok di atas perlu dibenahi terlebih dahulu sebelum masyarakat desa menggunakan sumber daya pembangunan yang ada. Dengan demikian maka penyelesaian terhadap kelima masalah krusial di atas merupakan prasyarat bagi pembangunan desa yang baik.

\section{PENUTUP}

\section{Kesimpulan}

Berdasarkan uraian hasil penelitian yang telah dibahas dalam bab dimuka, maka pada bagian ini dapat ditarik beberapa kesimpulan sebagai berikut:

1. Peran Badan Permusyawaratan Desa sebagai penyalur aspirasi masyarakat desa terhadap adanya pembahasan sebelum pembangunan sangat besar dan sudah dilaksanakan secara baik. Dalam mengakomodasi permasalahan dan pembangunan didesa, BPD juga sudah berperan cukup baik meskipun kadang kala terlihat sepinya kantor BPD di Desa Dulohupa yang mengakibatkan susahnya masyarakat untuk menyalurkan aspirasi, ide serta gagasan.

2. Faktor-faktor penghambat pengembangan organisasi Badan
Permusyawaratan Desa Dulohupa dapat diidentifikasi meliputi 2 (dua) faktor yakni faktor yang bersifat internal atau bersumber dari dalam organisasi sendiri dan faktor eksternal atau bersumber dari luar organisasi.

\section{Saran}

Upaya untuk mengoptimalkan pelaksanaan peran Badan Permusyawaratan Desa dalam menunjang pembangunan desa di Desa Dulohupa dari hasil temuan penelitian dapat direkomendasi saran untuk peningkatannya sebagai berikut:

1. Perlunya ditingkatkan koordinasi antara sesama anggota Badan Permusyawatan Desa di Desa Dulohupa dalam melaksanakan tugas pokok mereka demi kemajuan pembangunan di Desa Dulohupa.

2. Perlu adanya perubahan dalam format anggota Badan Permusyawaratan Desa pada pemilihan yang akan datang. Sebaiknya setiap dusun diwakili masing-masing satu orang anggota BPD sehingga aspirasi yang ada pada tiap-tiap dusun dapat terserap atau ditampung.

3. Perlu ditingkatkannya sumber daya manusia (SDM) bagi anggota BPD dengan cara melakukan pelatihanpelatihan bagi anggota BPD mengenai organisasi manajemen dan fungsi BPD di masyarakat.

\section{DAFTAR PUSTAKA}

Conyers, Dana, 1991, Perencanaan Di Dunia Ketiga, Jakarta : Gramedia,

Firman, B. Aji, Drs, Sirait, S. Martin, Drs, 1982, Perencanaan Dan Evaluasi, Suatu Studi Untuk Proyek Pembangunan, Jakarta : Bumi Aksara, Moleong, J. Lexy, 1993, Metodologi Penelitian Kualitatif. Bandung : P.T. Remaja Rosdakaria, 
Moekijat, 1988, Perencanaan Tenaga Kerja, Bandung : Pioner Jaya.

Nawawi, Hadari, 1983 Metode Penelitian Soasial, Yogyakarta : Gajah Mada University Press.

Ndraha, Taliziduhu, 1985, Pembangunan Desa dan Administrasi Pemerintahan Desa, Jakarta.: Yayasan Karya Dharma,

Nitisastro, Widjojo, 1985, Manajemen Pemerintahan, Jakarta.: Yayasan Penerbit Adm, 